\title{
PENGARUH PEMBELAJARAN MODEL PRAKTEK BLOK WEEK AND MONTH RELEASE DAN SIKAP WIRAUSAHA TERHADAP HASIL BELAJAR TUNE-UP
}

\author{
Jamiter Silalahi, Sahat Siagian, R. Mursid \\ Sekolah Menengah Kejuruan GKPS 2 Pematangsiantar, Sumatera Utara \\ jamiter_silalahi@gmail.com
}

\begin{abstract}
Abstrak: Penelitian ini bertujuan untuk: (1) Mengetahui perbedaan hasil belajar tune-up motor bensin siswa yang diajar dengan menggunakan pembelajaran model paktek blok week release dan model praktek blok month release, (2) Mengetahui perbedaan hasil belajar tune-up motor bensin yang memiliki sikap wirausaha positip dengan sikap wirausaha negatip, (3) Mengetahui interaksi antara model praktek dan sikap wirausaha terhadap hasil belajar tune-up motor bensin siswa. Hasil penelitian adalah (1) Hasil belajar tune-up motor bensin siswa yang diajar dengan model blok week release lebih tinggi daripada hasil belajar tune-up motor bensin siswa yang diajar dengan model blok month release, (2) Sikap wirausaha positip dan sikap wirausaha negatip memberikan hasil belajar lebih tinggi dengan hasil belajar tune-up motor bensin pada kelompok siswa yang mempunyai sikap wirausaha positip sedangkan skor rata-rata hasil belajar tune-up motor bensin pada kelompok siswa yang mempunyai sikap wirausaha negatif. (3) terdapat interaksi antara model praktek dengan sikap wirausaha terhadap hasil belajar tune-up motor bensin, hal ini terbukti dari hasil penelitian yang menunjukkan bahwa bagi kelompok siswa yang memiliki sikap wirausaha positip memperoleh nilai hasil belajar lebih baik bagi yang diajar dengan pembelajaran model praktek blok week release, sedangkan bagi siswa yang sikap wirausaha negatip memperoleh nilai hasil belajar lebih baik bagi yang diajar dengan menggunakan pembelajaran model praktek blok month release.
\end{abstract}

Kata Kunci: model praktek, blok week and monthrelease, sikap wirausaha, tune-up

\begin{abstract}
This study aims to: (1) Know the differences in learning outcomes of petrol motorcycle tune-up students who are taught by using the learning model block week release model and block release month practice models, (2) Know the differences in learning outcomes of gasoline motor tune-up learning that have an attitude Positive entrepreneurship with negative entrepreneurial attitudes, (3) Knowing the interaction between practice models and entrepreneurial attitudes towards learning outcomes of students' gasoline motor tune-ups. The results of the study are (1) The results of learning the gasoline motorcycle tune-up of students taught with the block model week release are higher than the learning outcomes of the gasoline motorcycle tune-up of students taught by the month release block model, (2) Positive entrepreneurial attitudes and negative entrepreneurial attitudes provide higher learning outcomes with gasoline motorcycle tune-up learning outcomes in groups of students who have positive entrepreneurial attitudes while the average score of learning results in gasoline motor tune-ups in groups of students who have negative entrepreneurial attitudes. (3) there is an interaction between the practice model and the entrepreneurial attitude towards learning outcomes of gasoline motorcycle tune-ups, this is evident from the results of the study which shows that for groups of students who have positive entrepreneurial attitudes get better learning outcomes for those taught by learning the practical model block week release, while students with negative entrepreneurial attitudes get better learning outcomes for those who are taught using the month release block practice model.
\end{abstract}

Keywords: practice model, block week and month release, entrepreneurial attitude, tune-up

\section{PENDAHULUAN}

Pendidikan merupakan unsur terpenting dalam usaha mencerdaskan kehidupan bangsa. Negara akan maju dan berkembang apabila diikuti dengan peningkatan pendidikan yang lebih baik. Kemajuan pendidikan akan memberikan dampak positif dalam upaya peningkatan sumber daya manusia. Dunia 
pendidikan saat ini sedang memasuki era yang ditandai dengan gencarnya inovasi teknologi, pemakaian dan pemanfaatan teknologi di dunia kerja semakin berkembang sehingga menuntut adanya penyesuaian sistem pendidikan yang selaras dengan tuntutan dunia kerja.

Miarso (2007:485) mengatakan bahwa "sumber daya manusia merupakan modal dasar pembangunan terpenting". Lebih lanjut dijelaskan pendidikan untuk pembangunan kualitas manusia meliputi segala aspek perkembangan manusia dalam harkatnya sebagai makhluk yang berakal budi, sebagai pribadi, sebagai masyarakat dan sebagai warga negara. Pendidikan harus mencerminkan proses memanusiakan manusia dalam arti mengaktualisasikan semua potensi yang dimilikinya menjadi kemampuan yang dapat dimanfaatkan dalam kehidupan sehari-hari di masyarakat luas.

Sekolah Menegah Kejuruan GKPS 2 Pematangsiantar adalah salah satu Sekolah kejuruan rumpun Teknologi Mekanik Otomotif yang mengelola beberapa bidang keahlian serta terbagi dalam beberapa program keahlian. Bidang keahlian teknik mesin program keahlian teknik automotif merupakan bidang keahlian yang menjadi favorit bagi pelajar. SMK GKPS 2 Pematangsiantar, mengembangkan kualitasnya dengan menambah jumlah guru adaptif, normatif dan produktif serta sarana dan prasarana praktek pada masing-masing program keahlian. Hal yang memprihatinkan dapat dilihat adalah hasil belajar siswa yang belum mencapai harapan.

Hasil survey awal dan data yang didapatkan di SMK GKPS 2 Pematangsiantar, ditemukan bahwa sebagian besar guru mata diklat produktif pada saat melaksanakan pembelajarann hanya sekedar pengenalan dan pemahaman konsep tanpa menguraikan lebih mendalam materi dan menghubungkan antar materi yang dipelajari, model mengajar sebagian besar dilaksanakan dengan bertutur secara verbal dengan komunikasi lebih banyak satu arah.

Dalam kurikulum KTSP terdapat mata diklat yang secara khusus membahas masalah yaitu mata diklat Tune Up Motor Bensin. Mata diklat Tune UP Motor Bensin diajarkan kepada seluruh siswa SMK dalam berbagai bidang keahlian. Tune Up Motor Bensin merupakan mata diklat yang sangat berpengaruh terhadap pengembangan kompetensi dasar kejuruan dan kompetensi kejuruan untuk setiap bidang keahlian. Dengan mempelajari dan mengaplikasikannya dalam setiap bidang keahlian masing-masing, akan semakin memperjelas hubungan antara Tune Up Motor Bensin dengan kompetensi kejuruan. Secara umum mata diklat Tune Up Motor Bensin membahas mengenai kompetensi cara pemeliharaan, perawatan dan perbaikan motor bensin dengan penerapan sikap dan perilaku kerja yang selalu ingin maju, merumuskan cara pemecahan masalah, mengembangkan kopetensi untuk berwirausaha, membangun komitmen bagi diri sendiri.

Menurut Dunkin dan Biddle yang dikutip Sagala (2009:63) Proses pembelajaran atau pengajaran kelas (classroom teaching) berada pada empat variable interaksi yaitu: 1) variabel pertanda (presage variables) berupa pendidik; 2) variabel konteks (context variables) berupa peserta didik, sekolah, dan masyarakat; 3) variabel proses (proses variables) berupa interaksi peserta didik dengan pendidik; dan 4) variabel produk (product variables) berupa perkembangan peserta didik dalam jangka pendek maupun jangka panjang. Proses pembelajaran akan berlangsung dengan baik jika pendidik mempunyai kompetensi yaitu: 1) kompetensi subtansi materi pembelajaran atau penguasaan materi pelajaran, dan 2) kompetensi metodologi pembelajaran.

Menyikapi masalah diatas, perlu adanya upaya yang dilakukan oleh guru untuk menggunakan Model pembelajaran yang membuat suasana pembelajaran menjadi lebih menyenangkan sehingga dapat menumbuhkan sikap belajar siswa untuk belajar. Rogers yang dikutip Dimyati dan Mudjiono (2009:16) mengemukakan pentingnya guru memperhatikan prinsip pendidikan. Prinsip pendidikan dan pembelajaran tersebut sebagai berikut: 1) Menjadi manusia berarti memiliki kekuatan wajar untuk belajar; 2) Siswa akan mempelajari hal-hal yang bermakna bagi dirinya; 3) Pengorganisasian bahan pengajaran berarti mengorganisasikan bahan dan ide baru, sebagai yang bermakna bagi siswa; 4) Belajar yang bermakna dalam masyarakat modern berarti belajar tentang proses-proses belajar, keterbukaan belajar mengalami sesuatu, bekerja sama dengan melakukan pengubahan diri terusmenerus; 5) Belajar yang optimal akan terjadi, bila siswa berpartisipasi secara betanggung jawab dalam proses belajar; 6) B belajar mengalami (experiential learning) dapat terjadi, bila siswa mengevaluasi diri sendiri. Belajar 
mengalami dapat memberi peluang untuk belajar kreatif (self evaluation) dan kritik diri; 7) Belajar mengalami menuntut keterlibatan siswa penuh dan sungguh-sungguh.

Dalam menerapkan pembelajaran dengan model praktek, siswa ditempatkan sebagai pusat dari proses pembelajaran, anak didik tidak menjadi obyek pendidikan. Selain faktor-faktor dari guru, dan factor dari dalam diri siswa juga berpengaruh dalam proses pembelajaran. Selain model praktek yang digunakan oleh guru, hasil belajar siswa dipengaruhi oleh berbagai faktor, antara lain sebagai mana yang dikemukakan oleh slameto (2010:188) faktor-faktor lain yang mempengaruhi hasil belajar siswa adalah sikap. Sikap merupakan suatu yang dipalajari, dan sikap menetukan bagaimana individu bereaksi terhadap situasi serta menentukan apa yang dicari individu dalam kehidupan.

Menurut David Mc. Clelland yang dikutip Mudjiarto (2006:27) hasil penelitian menunjukkan bahwa bagi mereka yang memiliki keinginan berprestasi lebih tinggi teryata sekitar $66 \%$ diantaranya memilih karier sebagai pengusaha, sementara $34 \%$ lainnya memilih pekerjaan bidang lain.

Dari beberapa fenomena di atas, maka dalam penelitian ini upaya untuk meningkatkan hasil belajar Tune Up Motor Bensin siswa perlu diterapkan suatu Model praktek yang mampu menyampaikan materi kepada siswa secara lebih mendalam. Model praktek yang diterapkan adalah model praktek blok week release dan blok month release. Salah satu karakteristik siswa adalah sikap wirausaha yang diprediksi akan menentukan keefektifan pembelajaran model praktek, oleh karena itu sikap wirausaha siswa salah satu variable yang dilibatkan dalam penelitian ini.

\section{Hakikat Pembelajaran Model Praktek}

Belajar adalah adanya perubahan yang relative permanen pada pengetahuan atau perilaku seseorang karena pengalaman. Pembelajaran adalah sarana untuk mencapai tujuan belajar. Belajar, yang dapat terlihat dengan adanya perubahan pada pengetahuan, keterampilan atau sikap, merupakan kriteria atau ukuran pembelajaran. (Mayer, 1982 dalam Barbara dan Rita 1994: 13). Model praktek sering dikatakan Model latihan atau training merupakan cara mengajar untuk memperoleh suatu keterbiasaan, ketepatan, dan keterampilan dalam sesuatu pekerjaan. Menurut
Sagala (2009: 217) Model latihan (drill) atau Model training merupakan cara mengajar yang baik untuk menanamkan kebiasaan-kebiasaan tertentu. Juga sebagai sarana untuk memperoleh suatu ketangkasan, ketetapan, kesempatan dan keterampilan. Model latihan pada umumnya digunakan untuk memperoleh suatu ketangkasan atau keterampilan dari apa yang telah dipelajari. Mengingat latihan ini kurang mengembangkan bakat atau inisiatif siswa untuk berpikir, maka hendaknya latihan disiapkan untuk mengembangkan kepampuan motorik yang sebelumnya dilakukan diagnosis agar kegiatan bermanfaat bagi pengembangan motorik. Model latihan mempunyai kebaikankebaikan, antara lain adalah: (1) pembentukan kebiasaan yang diklakukan dengan mempergunakan Model ini akan menambah ketepatan dan kecakapan pelaksanaan, (2) pemanfaatan kebiasaan-kebiasaan tidak memerlukan banyak konsentrasi dalam pelaksanaanya, dan (3) pembentukan kebiasaan membuat gerakan-gerakan yang kompleks menjadi otomatis, habitation makes complex mpvement more automatic.

Karakteristik Model latihan menurut Syaiful (2006: 96) menyatakan sebagai berikut: (1) Untuk memperoleh kecakapan motorik, seperti menulis, melafalkan huruf, kata-kata atau kalimat, membuat alat-alat, menggunakan alat-alat (mesin, permainan, dan atletik) dan trampil menggunakan peralatan olahraga, (2) Untuk memperoleh kecakapan mental seperti dalam seperti perkalian, menjumlahkan, pengurangan, pembagian tanda-tanda, dan sebaginya, (3) Untuk memperoleh kecakapan dalam bentuk asosiasi yang dibuat, seperti hubungan-hubungan huruf-huruf dalam ejaan, penggunaan simbol, membaca peta dan sebagainya, (4) Pembentukan kebiasaan yang dilakukan dan menambah ketepatan serta kecepatan pelaksanaan, (5) Pemanfaatan kebiasaan-kebiasaan yang tidak memerlukan konsentrasi dalam pelaksanaan, Pembentukan kebiasaan-kebiasaan membuat gerak-gerakan yang kompleks, rumit, menjadi lebih otomastis.

Perkembangan ilmu pengetahuan dan teknologi (IPTEK) yang cepat, menyebabkan fasilitas praktek siswa disekolah semakin tertinggal dibandingkan dengan fasilitas praktek kerja yang digunakan di industri. Oleh sebab itu diperlukan kerja sama yang saling menguntungkan antara dunia pendidikan dengan industri yang memenuhi relevansi 
program yang disiapkan dengan kebutuhan masyarakat. Untuk merealisasikan hai tersebut pihak sekolah dan dunia industri (DU/DI) melaksanakan program bersama yang disebut praktek prakerin, sehingga didalam susunan program pendidikan dan latihan SMK terdapat paket keahlian produktif yang dilaksanakan di industri atau sebahagian di sekolah.

\section{Proses Pelaksanaan Model Praktek}

Menurut Soewarni, yang dikutip Wena (1996: 228) proses pelaksanaan Praktek Kerja Industri dilakukan oleh siswa di industri, baik berupa industri besar, menengah maupun industri kecil atau industri rumah tangga. Dalam pelaksanaan Praktek Kerja Industri ini, proses langkah-langkah pelaksanaan praktek harus tetap mengacu pada desain pembelajaran yang telah ditetapkan. Disamping itu, pelaksanaan praktek kerja industri dapat berupa Model blok week release atau berupa Model block month release.

\section{1). Model Praktek Blok Week Release}

Dalam penyelenggaraan model blok week release waktu belajar dalam satu minggu, digunakan satu minggu di sekolah dan satu minggu di industri, tergantung kesepakatan antara pihak sekolah dan pihak industri. model blok week release, dimana siswa belajar di industri/perusahaan selama satu minggu penuh pada jam kerja indutri/perusahaan untuk mendapatkan penguasaan keahlian di dunia kerja. Sedangkan di sekolah satu minggu untuk mempelajari mata pelajaran yang tidak terpogram di indutri/perusahaan sesuai dengan kurikulum serta mengikuti evaluasi kegiatan baik yang didapat di perusahaan/industri maupun di sekolah sesuai dengan kurikulum.

Dalam hal ini pihak sekolah mengontrol siswa dan mengatur jadwal praktek siswa pada saat pelaksanaan pembelajaran model praktek dan siswa saat belajar di sekolah. Menurut Winkel (2004), supaya usaha pendidikan dan pengajaran di suatu sekolah dapat berlangsung sebagaimana mestinya, kerja sama propesional antara tenaga-tenaga pengajar dan pimpinan sekolah adalah syarat mutlak, baik melalui kontak informal maupun formal. Pada pembelajaran praktek selama satu minggu, siswa akan melaksanakan praktek, minggu pertama melakukan orientasi, yakni pengenalan industrI/perusahaan, dan pemahaman peraturan dan keselamatan kerja.
Selanjudnya dibawah bimbingan instruktur industri, siswa akan menerima petunjuk dan prosedur kerja, keselamatan kerja baik alat yang dipakai. Dalam blok week release siswa mempunyai kesempatan disekolah untuk mempelajari lebih jauh hal-hal baru yang dijumpai dalam model praktek setiap minggunya kegiatan siswa disekolah untuk bidang keahlian produktif melakukan pengulangan bagian-bagian keterampilan yang mendukung kopetensi yang harus dikuasai siswa.

Menurut Carol yang dikutip Suryosubroto (1997) bahwa tingkat penguasaan bahan adalah fungsi dari waktu yang digunakan secara sunguh-sungguh untuk belajar sewaktu yang benar-benar dibutuhkan untuk mempelajari suatu bahan pelajaran. Hal ini mengandung makna bahwa keberhasilan siswa memperoleh kompetensi yang diingainkan dipegaruhi oleh waktu yang digunkan untuk belajar. Teori belajar tuntas menurut Carrol yang dikutip Ahmadi dan Praseya (1997) menyatakan bahwa secara sederhana konsep belajar tuntas mengajarkan bahwa bilamana siswa diberi kesempatan mempergunakan waktu yang dibutuhkan untuk belajar dan ia mempergunakannya sebaik-baiknya, maka ia akan mencapai tingkat hasil belajar seperti yang diharapkan.

Dengan kata lain, setiap siswa yang mempunyai kecakapan rata-rata jika diberi waktu yang cukup untuk belajar, mereka dapat diharapkan untuk menyelesaikan tugas-tugas belajarnya secara tuntas, sepanjang kodisi belajar yang tersedia cukup menguntungkan. Dengan demikian, tugas-tugas yang diberikan kepada siswa selama di industri/dunia usaha akan tercapai dan dapat berhasil memperoleh keterampilan jika diberikan waktu yang cukup yaitu satu minggu praktek di industry dan satu miggu belajar disekolah.

\section{2). Model Praktek Blok Month Release}

Pelaksanaan yang menggunakan model block month release waktu belajar dibagi pada hitungan bulan Dalam arti proses belajar dilakukan di sekolah satu bulan, kemudian satu bulan di industri. Pada model blok month release ini berarti siswa selama satu bulan berada di industri/perusahaan dan itu berlangsung dan satu bulan belajar disekolah. Selama di industry/perusahaan siswa tidak dibebani dengan materi pelajaran lain kecuali pelajaran produktif yang dipelajari di industri 
itu sendiri, sedangkan pelajaran normative dan adaptif di berikan disekolah.

Pelaksanaan model praktek Blok month release diberikan kegiatan berupa daftar mingguan (jurnal) untuk mencatat jenis pekerjaan yang dilakukan selama model praktek berlangsung. Daftar chek list ini merupkan pedoman bagi guru di sekolah untuk melanjudkan bagian-bagian mana saja yang mungkin harus diberikan kepada siswa disekolah sesuai kompetensi yang ditetapkan dalam kurikulum.

Berkaitan dengan peyelenggaraan model praktek tersebut sesuai dengan fase belajar keterampilan motorik, Winkel (1983) mengemukakan bahwa padafase kognitif siswa harus mempunyai interaksi untuk belajar, fase fiksasi dimana masa latihan mutlak diperlukan dan membutuhkan waktu yang cukup lama, dianjurkan supaya priode latihan maupun praktek diselingi priode istirahat untuk menghindari timbulnya rasa bosan dan kelelahan jasmani.

Berdasarkan uraian diatas dapat disimpulkan bahwa penggunaan waktu yang efektif dan efisien akan sangat membantu siswa mencapai hasil yang diharapkan. Dengan demikian model praktek blok month release sangat tepat digunakan untuk mencapai kompetensi Tune-up motor bensin, hal ini sejalan dengan yang dikemukakan Suryobroto (1997), bahwa semakin lama siswa menggunakan waktu secara bersungguhsungguh untuk belajar, semakin tinggi tingkat penguasaan terhadap bahan yang dipelajari. Dalam kondisi belajar tertentu, waktu yang digunakan untuk belajar dan waktu yang dibutuhkan untuk menguasai bahan pelajaran tidak saja dipengaruhi oleh sifat dari individu tetapi juga oleh karakteristik dari pengajar.

Tabe 1. Model Praktek Blok Wweek Release Dan Blok Month Release

\begin{tabular}{|l|l|l|l|}
\hline No & Minggu & \multicolumn{1}{|c|}{ Model blok week release } & \multicolumn{1}{c|}{ Model blok month release } \\
\hline 1 & Satu & $\begin{array}{l}\text { Praktek diindustry/Perusahaan dan } \\
\text { membuat/mengisi daftar kegiatan } \\
\text { mingguan yang telah disediakan }\end{array}$ & $\begin{array}{l}\text { Praktek di industry/Perusahaan dan } \\
\text { membuat/mengisi daftar kegiatan } \\
\text { mingguan yang telah disediakan }\end{array}$ \\
\hline 2 & Dua & $\begin{array}{l}\text { Disekolah belajar mengikuti jam belajar } \\
\text { untuk normative dan adaptif, untuk } \\
\text { produktif praktek dilakukan pengulangan } \\
\text { kerja yang dilakukan di industry secara } \\
\text { berkelompok }\end{array}$ & $\begin{array}{l}\text { Praktek di industri/Perusahaan dan } \\
\text { membuat/mengisi daftar kegiatan } \\
\text { mingguan yang telah disediakan }\end{array}$ \\
\hline 3 & Tiga & $\begin{array}{l}\text { Praktek di industri/Perusahaan dan } \\
\text { membuat/mengisi daftar kegiatan } \\
\text { mingguan yang telah disediakan }\end{array}$ & $\begin{array}{l}\text { Praktek di industri/Perusahaan dan } \\
\text { membuat/mengisi daftar kegiatan } \\
\text { mingguan yang telah disediakan }\end{array}$ \\
\hline 4 & Empat & $\begin{array}{l}\text { Disekolah belajar mengikuti jam belajar } \\
\text { untuk normative dan adaptif, untuk } \\
\text { produktif praktek dilakukan pengulangan } \\
\text { kerja yang dilakukan di industri secara } \\
\text { berkelompok }\end{array}$ & $\begin{array}{l}\text { Praktek di industri/Perusahaan dan } \\
\text { membuat/mengisi daftar kegiatan } \\
\text { mingguan yang telah disediakan }\end{array}$ \\
\hline 5 & Lima & $\begin{array}{l}\text { Praktek di industri/Perusahaan dan } \\
\text { membuat/mengisi daftar kegiatan } \\
\text { mingguan yang telah disediakan }\end{array}$ & $\begin{array}{l}\text { Disekolah belajar mengikuti jam } \\
\text { belajar untuk normative dan } \\
\text { adaptif, untuk produktif praktek } \\
\text { dilakukan pengulangan kerja yang } \\
\text { dilakukan di industri secara } \\
\text { berkelompok }\end{array}$ \\
\hline 6 & Enam & $\begin{array}{l}\text { Disekolah belajar mengikuti jam belajar } \\
\text { untuk normative dan adaptif, untuk } \\
\text { produktif praktek dilakukan pengulangan } \\
\text { kerja yang dilakukan di industri secara } \\
\text { berkelompok } \\
\text { belajar untuk normative dan } \\
\text { adaptif, untuk produktif praktek } \\
\text { dilakukan pengulangan kerja yang } \\
\text { dilakukan di industri secara } \\
\text { berkelompok }\end{array}$ \\
\hline $\begin{array}{l}\text { Praktek di industri/Perusahaan dan } \\
\text { membuat/mengisi daftar kegiatan } \\
\text { mingguan yang telah disediakan }\end{array}$ & $\begin{array}{l}\text { Disekolah belajar mengikuti jam } \\
\text { belajar untuk normative dan } \\
\text { adaptif, untuk produktif praktek }\end{array}$ \\
\hline
\end{tabular}




\begin{tabular}{|l|l|l|l|}
\hline No & Minggu & \multicolumn{1}{|c|}{ Model blok week release } & \multicolumn{1}{|c|}{ Model blok month release } \\
\hline 8 & Delapan & $\begin{array}{l}\text { Disekolah belajar mengikuti jam belajar } \\
\text { untuk normative dan adaptif, untuk } \\
\text { produktif praktek dilakukan pengulangan } \\
\text { kerja yang dilakukan di industri secara } \\
\text { berkelompok } \\
\text { dilakukan di industri secara } \\
\text { berkelompok }\end{array}$ & $\begin{array}{l}\text { Disekolah belajar mengikuti jam } \\
\text { belajar untuk normative dan } \\
\text { adaptif, untuk produktif praktek } \\
\text { dilakukan pengulangan kerja yang } \\
\text { dilakukan di industri secara } \\
\text { berkelompok }\end{array}$ \\
\hline 9 & $\begin{array}{l}\text { Sembila } \\
\text { n }\end{array}$ & $\begin{array}{l}\text { Praktek di industri/Perusahaan dan } \\
\text { membuat/mengisi daftar kegiatan } \\
\text { mingguan yang telah disediakan }\end{array}$ & $\begin{array}{l}\text { Praktek di industri/Perusahaan dan } \\
\text { membuat/mengisi daftar kegiatan } \\
\text { mingguan yang telah disediakan }\end{array}$ \\
\hline 10 & Sepuluh & $\begin{array}{l}\text { Disekolah belajar mengikuti jam belajar } \\
\text { untuk normative dan adaptif, untuk } \\
\text { produktif praktek dilakukan pengulangan } \\
\text { kerja yang dilakukan di industri secara } \\
\text { berkelompok }\end{array}$ & $\begin{array}{l}\text { Praktek di industri/Perusahaan dan } \\
\text { membuat/mengisi daftar kegiatan } \\
\text { mingguan yang telah disediakan }\end{array}$ \\
\hline 11 & Sebelas & $\begin{array}{l}\text { Praktek di industri/Perusahaan dan } \\
\text { membuat/mengisi daftar kegiatan } \\
\text { mingguan yang telah disediakan }\end{array}$ & $\begin{array}{l}\text { Praktek di industri/Perusahaan dan } \\
\text { membuat/mengisi daftar kegiatan } \\
\text { mingguan yang telah disediakan }\end{array}$ \\
\hline 12 & $\begin{array}{l}\text { Duabela } \\
\text { s }\end{array}$ & $\begin{array}{l}\text { Disekolah belajar mengikuti jam belajar } \\
\text { untuk normative dan adaptif, untuk } \\
\text { produktif dilakukan di industri secara } \\
\text { berkelompok }\end{array}$ & $\begin{array}{l}\text { Praktek di industri/Perusahaan dan } \\
\text { membuat/mengisi daftar kegiatan } \\
\text { mingguan yang telah disediakan }\end{array}$ \\
\hline
\end{tabular}

\section{Hakekat Sikap Wirausaha.}

Karakteristik siswa adalah aspek yang meliputi berupa bakat, motif atau matifasi berprestasi, presepsi, sikap, lokus kendali, kemampuan berpikir logis, kreativitas, kemampuan berpikir kreatif, ketekunan belajar, kecerdasan, dan kualitas perseorangan lainnya, menurut Thomas yang dikutip Zaluku (2009:39).

Sikap adalah pernyataan-pernyataan evaluative baik yang diinginkan atau yang tidak diinginkan mengenai obyek, orang, atau peristiwa. Sikap mencerminkan bagaimana seseorang merasakan sesuatu menurut Stepen P. Robin (2003: 93). Menurut Slameto (2010:188) Faktor lain yang mempengaruhi hasil belajar adalah sikap. Sikap merupakan sesuatu yang dipelajari, dan sikap menentukan bagaimana individu bereaksi terhadap situasi serta menentukan apa yang dicari individu dalam kehidupan. Rumusan diatas menyatakan bahwa sikap mengandung tiga komponen, yaitu komponen kognitif, komponen afektif, dan komponen tingkah laku. Sikap selalu berkenan dengan suatu obyek, dan sikap terhadap obyek ini disertai dengan perasaan positif dan negative. Orang memepunyai sikap positif terhadap suatu obyek yang bernilai dalam pandangannya, dan ia bersipak negatif terhadap obyek yang dianggap tidak bernilai dan atau juga merugikan.

Selanjudnya yang dikemukakan Ellis yang dikutip Purwanto (2010:141) yang ssangat memegang peranan penting di dalam sikap adalah factor perasaan atau emosi, dan factor kedua reaksi/respon, atau kecenderungan untuk bereaksi. Dalam beberapa hal, sikap merupakan penentu yang penting dalam tingkah laku manusia. Sebagai reaksi maka sikap selalu berhubungan dengan dua alternative, yaitu senag atau tidak senang, menurut dan melaksanakannya atau menjauhi/menghindari sesuatu.

Bogardus, LaPierrre, Mead dan Gordon Allport yang dikutip Azwar (2005) menyatakan bahwa sikap merupakan semacam kesiapan untuk bereaksi terhadap suatu objek dengan cara-cara tertentu. Kesiapan adalah kecenderungan potensial untuk bereaksi dengan cara tertentu apabila individu dihadapkan pada suatu stimulus yang menghendaki adanya respons. Selanjutnya Secord \& Backman yang dikutip Azwar, (2005) menyatakan bahwa sikap merupakan keteraturan tertentu dalam hal pemikiran (kognisi), perasaan (afeksi), dan predisposisi tindakan (konasi) seseorang terhadap suatu aspek di lingkungan sekitarnya. 
Seorang wirausaha adalah individu yang mempraktekkan sikap tekun dalam melaksanakan kerja. Berdasarkan kata konsep tersebut, yaitu wira yang menyatakan antara lain dapat diartikan sebagai pahlawan, dan usaha- yang dapat diartikan sebagai melakukan kegiatan ekanomi, wirausaha dapat didefinisikan dengan berikut: seseorang yang dengan gigih berusaha untuk menjalankan sesuatu kegiatan bisnis dengan tujuan untuk mencapai hasil yang dapat dibanggakan. Seseorang dapat digolongkan sebagai wirausaha apabila mempunyai keyakinan diri yang tinggi, yang berkeyakinan bahwa dirinya mempunyai kemampuan untuk mencapai sasaran yang diinginkannya. Kewirausahaan sebagai sifat dan keahlian yang dimiliki oleh para wirausaha. Dengan demikian kewirausahaan dapat diartikan sebagai karakter seorang wirausaha, yang meliputi hal berikut berani mengambil resiko, bijaksana dalam membuat keputusan, pandai melihat kesempatan yang terbuka dan berkemampuan menjadi manejer yang baik menurut Sadono Sukirno (2006:367)

Keberhasilan dan kesuksesan menjadi wirausaha selalu berawal dari impian. Namun tidak semua orang berhasil dalam mewujudkan impiannya. Hal ini bergantung pada bagaimana kita bisa mengarahkan impian kita kepada kenyataan yang kita harapkan. Orang yang berhasil mewujudkan impiannya adalah orang yang dapat menyelaraskan antara impian dan tindakan. Suatu impian akan dapat dicapai jika kita tidak terlena dengan impian-impian kita dan selalu hidup dalam dunia impian, namun kita diharapkan untuk mau mengubah sikap dan tindakan kita menuju kearah impian yang kita cita-citakan. Jika saat ini kondisi dan keadaan kita sangat jauh dari impian yang kita miliki, maka kita harus mengubah perilaku dan tindakan kita untuk mencapainya. Kita tidak dapat mengharapkan hasil yang berbeda dengan melakukan hal yang sama. Dengan kata lain, kita harus keluar dari zona kenyamanan dan segera melakukan hal-hal yang dapat membantu kita dalam mencapai impian-impian kita (Aribowo Prijosaksono dan Sri Bawono ,2004:4).

Untuk menjadi seorang wirausaha yang sukses, tidak ada hal yang lebih penting dari kemauan dan kemampuan kita untuk terus menerus belajar dan membangun kreativitas dari apa yang kita pelajari setiap saat. Kemauan untuk belajar, berubah, dan bertumbuh serta tidak takut melakukan kesalahan/kegagalan merupakan bahan bakar bagi pertumbuhan dan perkembangan bisnis kita. Kebanyakan orang tidak sukses dalam hidup karena mereka tidak bersedia melewati periode ketidakpastian pribadi dan frustrasi emosional. Ini disebabkan karena kita belajar di sekolah bahwa kesalahan itu jelek dan harus dihindari. Jadi kita meninggalkan sekolah, duduk di dalam sarang dan tidak pernah belajar untuk terbang. (Robert T. Kiyosaki, 2004:45). Menurut Sadono Sukirno (2006:371) Seorang wirausaha yang effektif dan sukses mempunyai beberapa sifat dan kepribadian berikut: 1) Percaya Diri, 2) Berorientasi Kemanusiaan, 3) Berorientasi Tugas dan Keputusan, 4) Sikap Keaslian Ide dan Kreatif, 5) Berorientasi Masa Depan, 6) Bersedia dalam Mengambil Resiko, 7) Kemampuan Membuat Keputusan, 8) Berorientasi Perencanaan, 9) Kemampuan Mendirikan Perusahaan, dan 10) Kemampuan Manajemen.

Rumusan penelitian adalah: (1) Apakah Hasil Belajar Tune Up Motor Bensin siswa yang diajar dengan Model praktek blok week release lebih tinggi dari pada siswa yang diajar dengan Model praktek blok month release?; (2) Apakah Hasil Belajar Tune Up Motor Bensin siswa yang memiliki sikap wirausaha positif lebih baik dari pada siswa yang memiliki sikap wirausaha negatif?; dan (3) Apakah terdapat interaksi antara pembelajaran model praktek dengan sikap wirauasa dalam mempengaruhi hasil belajar Tune Up Motor Bensin?

\section{METODE}

Penelitian ini direncanakan akan dilaksanakan di Sekolah Menengah Kejuruan (SMK) GKPS 2 Pematangsiantar Kabupaten Simalungun. Perlakuan atau treatment penelitian dilaksanakan dengan menyesuaikan jadwal mata diklat Tune Up Motor Bensin. Populasi dalam penelitian ini adalah seluruh siswa kelas XI (sebelas) bidang keahlian teknik mesin program keahlian teknik Mekanik Otomotif SMK GKPS 2 Pematangsiantar, yang terdiri dari 8 (delapan) kelas. Dari keseluruhan populasi ditetapkan 2 (dua) kelas yang menjadi sampel yaitu kelas $\mathrm{XIo}_{1}=32$ Orang, $\mathrm{XIo}_{2}=32$ Orang dan orang, dengan jumlah keseluruhan 64 orang. Sampel penelitian diperoleh dengan menggunakan cara cluster random sampling (teknik pengambilan sampel secara acak).

Model yang dipergunakan dalam penelitian ini adalah Model quasi eksperimen 
dengan desain penelitian faktorial $2 \times 2$. Melalui desain ini akan melibatkan dua kelompok sampel masing-masing ditetapkan sebagai kelompok eksperimen dengan menggunakan pembelajaran model praktek blok week release dan Model praktek blok month release dalam pembelajaran mata diklat Tune Up Motor Bensin. Akhir dari eksperimen ini diharapkan mendapat informasi tentang perbedaan hasil belajar mata diklat Tune Up
Motor Bensin melalui Model praktek blok week release yang dibandingkan dengan model praktek blok month release. Model praktek blok week release dan model praktek blok month release sebagai variabel bebas sedangkan sikap wirausaha dibagi menjadi sikap wirausaha positip dan sikap wirausaha negatip sebagai variabel moderator dan hasil belajar mata diklat Tune Up Motor Bensin sebagai variabel terikat.

Tabel 1. Rancangan Ekesperimen Desain Faktorial $2 \times 2$

\begin{tabular}{|c|c|c|}
\hline $\begin{array}{l}\text { Model Pembelajaran } \\
\text { Sikap Wirausaha(B) }\end{array}$ & $\begin{array}{c}\text { Model Praktek Blok Week } \\
\text { Release } \\
\left(\mathrm{A}_{1}\right)\end{array}$ & $\begin{array}{c}\text { Model Praktek Blok Month } \\
\text { Release } \\
\left(\mathrm{A}_{2}\right)\end{array}$ \\
\hline Positip $\left(\mathrm{B}_{1}\right)$ & $\mathrm{A}_{1} \mathrm{~B}_{1}$ & $\mathrm{~A}_{2} \mathrm{~B}_{1}$ \\
\hline Negatip $\left(B_{2}\right)$ & $A_{1} B_{2}$ & $\mathrm{~A}_{2} \mathrm{~B}_{2}$ \\
\hline
\end{tabular}

Keterangan:

A $\quad=$ Model pembelajaran praktek.

$\mathrm{A}_{1} \quad=$ Model praktek blok week release

$\mathrm{A}_{2} \quad=$ Model praktek blok month release

B = Sikap wirausaha

$\mathrm{B}_{1} \quad=$ Sikap wirausaha positip

$\mathrm{B}_{2} \quad=$ Sikap wirausaha negatip

$\mathrm{A}_{1} \mathrm{~B}_{1}=$ Hasil belajar Hasil belajar Tune Up

Motor Bensin yang diajar dengan

Model praktek blok week release dan sikap wirausaha positip

$\mathrm{A}_{1} \mathrm{~B}_{2}=$ Hasil belajar Hasil belajar Tune Up Motor Bensin yang diajar dengan Model praktek blok week release dan sikap wirausaha negatip

$\mathrm{A}_{2} \mathrm{~B}_{1}=$ Hasil belajar Hasil belajar Tune Up Motor Bensin yang diajar dengan Model praktek blok month release dan sikap wirausaha positip

$\mathrm{A}_{2} \mathrm{~B}_{2}=$ Hasil belajar Hasil belajar Tune Up Motor Bensin yang diajar dengan Model praktek month release dan sikap wirausaha negatip.

Teknik analisis data yang digunakan adalah teknik statistik deskriptif dan inferensial. Teknik statistik deskriptif digunakan untuk mendeskripsikan data antara lain mean, median, standard deviasi dan kecenderungan data. Teknik statistik inferensial digunakan untuk menguji hipotesis penelitian, dimana teknik inferensial yang digunakan adalah teknik analisis varians (ANAVA) dua jalur dengan taraf signifikan $0,05 \%$.

Sebelum teknik analisis ini digunakan maka terlebih dahulu dilakukan uji persyaratan analisis, dilakukan dengan uji normalitas menggunakan uji Liliefors dan uji homogenitas menggunakan uji Bartlett (Sudjana, 2005: 261). Jika ada interaksi antar variabel, maka analisis dilanjutkan uji beda dengan menggunakan uji Scheffe. Jika jumlah subjek penelitian tiap sel tidak berbeda, namun bila tiap sel sama maka dilanjutkan dengan uji Tuckey.

Berdasarkan hipotesis penelitian yang telah dirumuskan di muka, maka berikut ini dapat disusun hipotesis statistik yang akan diuji sebagai berikut:

1. Hipotesis Pertama

$$
\begin{aligned}
& H o: \mu_{A l}=\mu_{A 2} \\
& H a: \mu_{A l} \neq \mu_{A 2}
\end{aligned}
$$

2. Hipotesis Kedua

Ho $: \mu_{B 1}=\mu_{B 2}$

$H a: \mu_{B 1} \neq \mu_{B 2}$

3. Hipotesis Ketiga

Ho : $A \times B=0$

$H a: A \times B \neq 0$

\section{Keterangan:}

$\mu_{A l}=$ Rata-rata hasil belajar Tune Up Motor Bensin siswa yang diajarkan dengan Pembelajaran Model praktek blok week release.

$\mu_{A 2}=$ Rata-rata hasil belajar Tune Up Motor Bensin siswa yang diajarkan pembelajaran Model praktek blok month release.

$\mu_{B 1}=$ Rata-rata hasil belajar Tune Up motor bensin siswa yang memiliki sikap wirausaha positif

$\mu_{B 2}=$ Rata-rata hasil belajar Tune Up motor bensin siswa yang memiliki sikap wirausaha negative. 
$\begin{array}{rlr}A \times B= & \begin{array}{l}\text { Interaksi antara } \\ \text { pembelajaran Model } \\ \text { dengan sikap wirausaha. }\end{array} & \text { ptraktegi } \\ & \end{array}$

HASIL PENELITIAN
Hasil
Berdasarkan data nilai tes hasil belajar Tune Up Motor Bensin siswa, langkah berikutnya adalah menghitung total nilai dan rata-rata nilai tiap kelompok perlakuan menurut tabel Anava, yang selanjutnya dapat digunakan sebagai dasar keputusan statistik untuk pengujian hipotesis.

Tabel 2. Hasil Statistik Deskriptif

\begin{tabular}{|c|c|c|c|c|c|c|c|}
\hline \multirow{2}{*}{\multicolumn{2}{|c|}{ Variabel }} & \multicolumn{4}{|c|}{ Model Praktek } & \multirow{2}{*}{\multicolumn{2}{|c|}{ Total }} \\
\hline & & \multicolumn{2}{|c|}{ WR } & \multicolumn{2}{|c|}{ MR } & & \\
\hline \multirow{12}{*}{ 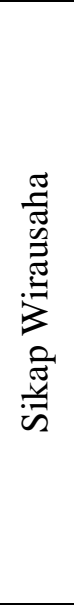 } & \multirow{6}{*}{ 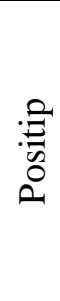 } & $\mathrm{n}$ & 16 & $\mathrm{~N}$ & 16 & $\mathrm{~N}$ & 32 \\
\hline & & $\sum \mathrm{X}$ & 1385 & $\sum X$ & 1292 & $\sum \mathrm{X}$ & 2677 \\
\hline & & $\mathrm{x} \square$ & 86.56 & $\mathrm{x} \square$ & 80.75 & $\mathrm{x} \square$ & 83.660 \\
\hline & & $s^{2}$ & 13.86 & $\mathrm{~s}^{2}$ & 34.73 & $s^{2}$ & 32.23 \\
\hline & & $\mathrm{s}$ & 3.723 & $\mathrm{~S}$ & 5.893 & $S$ & 5.677 \\
\hline & & $\mathrm{X} \square$ & 120097 & $\mathrm{X} \square$ & 104850 & $\mathrm{X} \square$ & 224947 \\
\hline & & $\mathrm{n}$ & 16 & $\mathrm{~N}$ & 16 & $\mathrm{~N}$ & 32 \\
\hline & & $\sum \mathrm{X}$ & 1198 & $\sum \mathrm{X}$ & 1210 & $\sum \mathrm{X}$ & 2408 \\
\hline & $\bar{\Xi}$ & $\mathrm{x} \square$ & 74.875 & $\mathrm{x} \square$ & 75.625 & $\mathrm{x} \square$ & 75.25 \\
\hline & $\mathbb{Z}^{\infty}$ & $\mathrm{s}^{2}$ & 25.72 & $\mathrm{~s}^{2}$ & 16.25 & $\mathrm{~s}^{2}$ & 20.45 \\
\hline & & $\mathrm{s}$ & 5.071 & $S$ & 4.031 & $S$ & 4.52 \\
\hline & & $\mathrm{X} \square$ & 90086 & $\mathrm{X} \square$ & 91750 & $\mathrm{X} \square$ & 181836 \\
\hline & & $\mathrm{n}$ & 32 & $\mathrm{~N}$ & 32 & $\mathrm{n}_{\mathrm{t}}$ & 64 \\
\hline & & $\sum X$ & 2583 & $\sum X$ & 2502 & $\sum X_{t}$ & 5085 \\
\hline & & $\mathrm{x} \square$ & 80.72 & $\mathrm{x} \square$ & 78.188 & $\mathrm{x} \square$ & 79.45 \\
\hline & & $\mathrm{s}^{2}$ & 54.4 & $\mathrm{~s}^{2}$ & 31.45 & $\mathrm{~s}^{2}$ & 43.87 \\
\hline & & $\mathrm{S}$ & 7.376 & $\mathrm{~S}$ & 5.608 & $\mathrm{~S}$ & 6.624 \\
\hline & & $\mathrm{X} \square$ & 210183 & $\mathrm{X} \square$ & 196600 & $\mathrm{X} \square$ & 406783 \\
\hline
\end{tabular}

\section{Pengujian Hipotesis}

Secara keseluruhan hasil Anava untuk pengujian hipotesis

Tabel 3. Rangkuman Hasil Anava Secara Keseluruhan Data Hasil Belajar Tune Up Motor Bensin

\begin{tabular}{|c|c|c|c|c|c|}
\hline Sumber variasi & Dk & JK & RJK & $F_{\text {hitung }}$ & $\begin{array}{c}F_{\text {tabel(1.60) }} \\
(\alpha=0.05)\end{array}$ \\
\hline Model Praktek & 1 & 102.516 & 102.516 & 4.528 & 4.00 \\
\hline Sikap wirausaha & 1 & 1130.641 & 1130.641 & 49.939 & \\
\hline Interaksi & 1 & 172.266 & 172.266 & 7.609 & \\
\hline Galat & 60 & 1358.438 & 22.641 & & \\
\hline Total & 63 & 2763.859 & & & \\
\hline
\end{tabular}

Karena ada interaksi antara model praktek dan sikap wirausaha dalam mempengaruhi hasil belajar Tune Up Motor Bensin, maka perlu dilakukan uji lanjutan (post hoc test), untuk mengetahui rata-rata hasil belajar sampel mana yang berbeda. Untuk melihat bentuk interaksi antara model praktek dan sikap wirausaha dalam mempengaruhi hasil belajar Tune Up Motor Bensin, dilakukan uji lanjut dengan menggunakan uji Tuckey. 
Tabel 4. Ringkasan Hasil Perhitungan Uji Tuckey

\begin{tabular}{|c|c|c|c|}
\hline $\begin{array}{c}\text { Nilai rata-rata kelompok } \\
\text { yang dibandingkan }\end{array}$ & $\mathrm{Q}$ & $\mathrm{Q}_{\text {tabel(3.66) }}$ & \multirow{2}{*}{ Keterangan } \\
\cline { 3 - 3 } & hitung & $\alpha=0,05$ & Signifikan \\
\hline$\mu \mathrm{A} 1 \mathrm{~B} 1$ dengan $\mu \mathrm{A} 2 \mathrm{~B} 1$ & 16,424 & 5,66 & Signifikan \\
\hline$\mu \mathrm{A} 1 \mathrm{~B} 1$ dengan $\mu \mathrm{A} 1 \mathrm{~B} 2$ & 33,031 & 5,66 & Signifikan \\
\hline$\mu \mathrm{A} 2 \mathrm{~B} 1$ dengan $\mu \mathrm{A} 2 \mathrm{~B} 2$ & 14,487 & 5,66 & Tidak Signifikan \\
\hline$\mu \mathrm{A} 1 \mathrm{~B} 2$ dengan $\mu \mathrm{A} 2 \mathrm{~B} 2$ & 2,120 & 5,66 & \\
\hline
\end{tabular}

Kriteria penerimaan jika : $\mathrm{Q}$ hitung $>$ $\mathrm{Q}_{\text {tabel, }}$ maka teruji secara signifikan. Berdasarkan hasil uji Tuckey pada Tabel 4.17. di atas dapat dilihat bahwa terdapat 4 (empat) pasang hipotesis statistik, yakni :

a. Dari hasil perhitungan menunjukkan bahwa $\mathrm{Q}_{\text {hitung }}=16,424>\mathrm{Q}_{\text {tabel }}=5,66$, sehingga memberikan keputusan menolak Ho. Dengan demikian, hipotesis penelitian yang menyatakan bahwa hasil belajar Tune Up Motor Bensin siswa jika diajar menggunakan model blok week release lebih tinggi dibandingkan dengan model blok month release untuk siswa yang memiliki sikap wirausaha positip teruji kebenarannya.

b. Dari hasil perhitungan menunjukkan $\mathrm{Q}_{\text {hitung }}$ $=33,031>\mathrm{Q}_{\text {tabel }}=5,66$, sehingga memberikan keputusan menolak Ho. Dengan demikian, hipotesis penelitian yang menyatakan bahwa Hasil belajar Tune Up Motor Bensin siswa dengan sikap wirausaha positip diajar menggunakan model blok week release tinggi dibandingkan dengan siswa yang memiliki sikap wirausaha negatip teruji kebenarannya.

c. Dari hasil perhitungan menunjukkan $Q_{\text {hitung }}$ $=14,487>\mathrm{Q}_{\text {tabel }}=5,66$, sehingga memberikan keputusan menolak Ho. Dengan demikian, hipotesis penelitian yang menyatakan bahwa hasil belajar Tune Up Motor Bensin siswa yang memiliki sikap wirausaha positip jika diajarkan dengan model blok week release, lebih tinggi dari pada hasil belajar Tune Up Motor Bensin siswa yang memiliki sikap wirausaha negatip jika diajarkan dengan model blok month release teruji kebenarannya. Dengan demikian terdapat perbedaan antara hasil belajar Tune Up Motor Bensin siswa yang diajar dengan model blok week release baik yang memiliki sikap wirausaha positip maupun yang memiliki sikap wirausaha negatip rendah.

d. Dari hasil perhitungan menunjukkan $\mathrm{Q}_{\text {hitung }}=$ $2,120<\mathrm{Q}_{\text {tabel }}=5,66$, sehingga memberikan keputusan menerima Ho. Dengan demikian hipotesis penelitian yang menyatakan bahwa hasil belajar Tune Up Motor Bensin siswa yang memiliki sikap wirausaha negatip jika menggunakan model blok week release lebih tinggi dibandingkan menggunakan model blok month release untuk sikap wirausaha tidak teruji kebenarannya. Dengan demikian tidak terdapat perbedaan antara hasil belajar siswa yang diajar dengan model blok week release dan memiliki sikap wirausaha negatip dengan hasil belajar siswa yang diajar dengan model blok month release dan memiliki sikap wirausaha negatip. Selanjutnya adanya interaksi antara variabel model praktek dan sikap wirausaha terhadap hasil belajar Tune Up Motor Bensin siswa, maka perlu diberikan gambaran grafik estimasi yang menunjukkan adanya interaksi tersebut. 


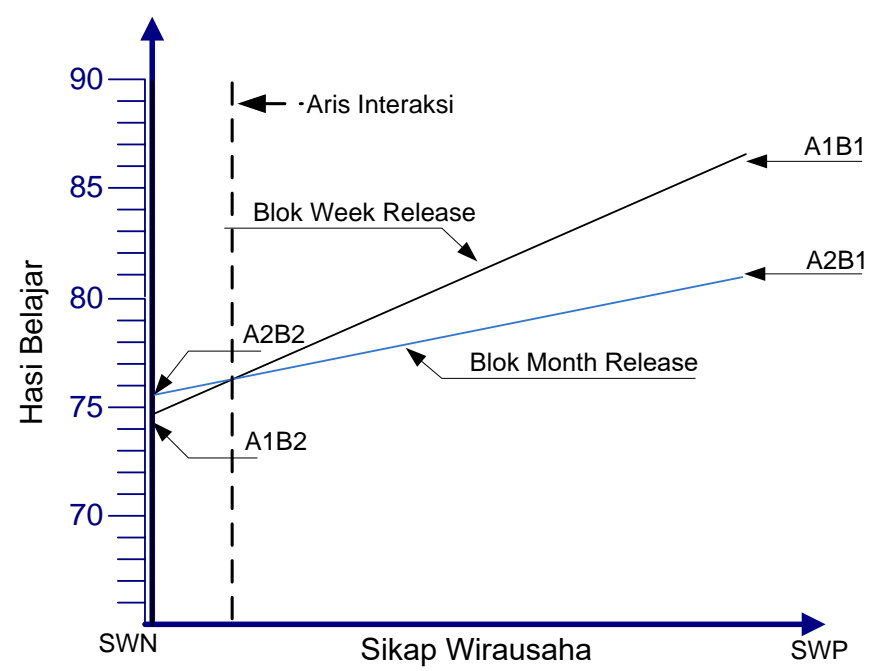

Gambar 1. Model Interaksi Antara Model Praktek Dan Sikap Wirausaha Terhadap Hasil Belajar Tune Up Motor Bensin Siswa

\section{Pembahasan}

1. Perbedaan Hasil Belajar Tune Up Motor Bensin Antara Siswa Yang Dibelajarkan Dengan Menggunakan Model Blok Week Release Dan Siswa Yang Dibelajarkan Dengan Menggunakan Model Blok Month Release

Pengguanaan model blok week release dalam pembelajaran Tune Up Motor Bensin memungkinkan siswa untuk berinteraksi langsung dan melakukan kontrol langsung pada sumber informasi sehingga memungkinkan siswa untuk langsung menemukan informasiinformasi yang sedang dipelajari. Pembelajaran dengan model blok week release saat praktek di sekolah, menunjukkan keingin tahuan yang lebih baik terhadap pekerjaan, namun bekerja buru-buru.

Pada pembelajaran ini guru mengacu pada penyajian informasi akademik yang baru yang penyampaiannya dapat dilakukan pada pelaksanaan praktek yang akan dilakukan siswa dalam praktek lanjutan. Pembelajaran dengan menggunakan model blok week release, siswa lebih cepat mendapatkan informasi dari guru pembimbing atau guru mata diklat di sekolah, karena waktu paraktek dilapangan lebih singkat tahapannya. Sementara pada proses dengan menggunakan model blok month release siswa lebih lama dalam melakukan praktek dilapangan, informasi yang kurang dipahami siswa dari tempat praktek tidak dapat dengan cepat melakukan interaksi dengan pembimbing atau guru mata diklat sehingga menimbulkan terlupakan hal-hal yang kurang dipahami. Berinteraksi atau melakukan kontrol langsung pada sumber informasi dan pembelajaran didominasi oleh pembimbing praktek lapangan (instruktur). Pada proses penyajiannya materi pembelajaran tidak dapat dilakukan pada setiap urutan-urutan (sekuensi) yang dikehendaki siswa.

Pembelajaran dengan menggunakan model blok month release, siswa relatif aktif melakukan kegiatan menerima dan mengikuti apa yang disampaikan oleh instruktur di lapangan. Pekerjaan praktek dilakukan sesuai dengan ketentuan pembimbing lapangan, sehingga siswa dalam mendapatkan informasi mendalam dengan materi pembelajaran kuran efektif. Guru menyampaikan materi secara terstruktur dengan harapan materi pelajaran yang disampaikan dapat dikuasai dengan baik dengan terfokus kepada kemampuan akademik.

Meskipun dalam penelitian diperoleh data bahwa hasil belajar Tune Up Motor Bensin siswa lebih tinggi jika dibelajarkan dengan model blok week release dari pada hasil belajar Tune Up Motor Bensin siswa yang dibelajarkan dengan model blok month release, namun dalam pelaksanaannya kedua model pembelajaran ini secara umum telah mampu meningkatkan pemahaman dan hasil belajar Tune Up Motor Bensin siswa. Dengan demikian dapat disimpulkan bahwa hasil belajar Tune Up Motor Bensin siswa yang dibelajarkan dengan menggunakan model blok week release lebih tinggi dibandingkan dengan hasil belajar Tune Up Motor Bensin siswa yang dibelajarkan dengan menggunakan model blok month release. 
2. Perbedaan Hasil Belajar Tune Up Motor Bensin Antara Siswa Yang Memiliki Sikap Wirausaha Positip Dan Siswa Yang Memiliki Sikap Wirausaha Negatip.

Hasil penelitian menunjukkan bahwa rata-rata hasil belajar Tune Up Motor Bensin siswa yang memiliki sikap wirausaha positip dengan rata-rata 83,660 , lebih tinggi daripada hasil belajar Tune Up Motor Bensin siswa yang memiliki sikap wirausaha negatip dengan ratarata 75,250. Hal ini mengindikasikan bahwa siswa yang memiliki sikap wirausaha positip lebih mampu memahami pelajaran Tune Up Motor Bensin dengan sumbangan kontribusi $65,64 \%$, dibandingkan dengan siswa yang memiliki sikap wirausaha negatip dengan sumbangan kontribusi $59,38 \%$. Siswa yang memiliki sikap wirausaha biasanya memiliki karakteristik berupa: Sikap wirausaha positif dan sikap wirausaha negatif. Sikap wirausaha positif dalam mental seseorang untuk melakukan suatu kegiatan yang lebih baik, lebih cepat, lebih efektif dan lebih efisien daripada kegiatan yang dilaksanakan sebelumnya terutama dalam masalah belajarnya. Sedangkan sikap wirausaha negatif adalah keterbatasan seseorang untuk melakukan suatu kegiatan yang lebih baik, lebih cepat, lebih efektif dan lebih efisien daripada kegiatan yang dilaksanakan sebelumnya terutama dalam masalah belajarnya.

Berdasarkan karakteristik sikap wirausaha diatas, siswa yang memiliki sikap wirausaha positip akan memperoleh hasil belajar yang lebih tinggi daripada siswa yang memiliki sikap wirausaha negatip, khususnya dalam pembelajaran Tune Up Motor Bensin karena dalam pembelajaran Tune Up Motor Bensin dibutuhkan kesabaran, keuletan, kreatifitas, motivasi dan kegigihan dalam mengetahui teknologi yang baru beserta aplikasinya yang sangat berhubungan dalam kehidupan sehari hari.

3. Interaksi Antara Pembelajaran Model Praktek Dan Sikap Wirausaha Terhadap Hasil Belajar Tune Up Motor Bensin.

Pembelajaran model praktek merupakan strategi pembelajaran yang menuntut adanya interaksi langsung dengan sumber materi pembelajaran sehingga dapat meningkatkan rasa keingin tahuan, minat, kreatifitas, motivasi belajar bagi siswa yang memilki sikap wirausaha positip. Sejalan dengan itu bagi siswa yang memiliki sikap wirausaha positip akan terpacu untuk lebih giat belajar dan mampu mengendalian diri karena mereka selalu optimis untuk dapat mengetahui materi pembelajaran Tune Up Motor Bensin dalam kehidupan sehari hari dan meningkatkan hasil belajarnya. Sedangkan siswa yang memilki sikap wirausaha negatip mungkin akan merasa khawatir dan was-was kalau mereka tidak mampu mengikuti pembelajaran. Hal ini terjadi karena sikap wirausaha adalah kurangnya motivasi belajar, kurangnya percaya diri akibat tidak mampu mengubah keadaan yang buruk. Siswa yang memilki sikap wirausaha negatip juga kurang mampu mengendalikan diri dan menangkap sinyalsinyal sosial yang mengisiaratkan apa yang dikehendaki oleh orang lain sehingga dalam komunikasi dengan guru dalam pembelajaran tidak terjadi dengan baik yang berakibat dapat melunturkan semangat belajar siswa jika dibelajarkan dengan menggunakan model blok week release.

Model blok month release merupakan pembelajaran yang berorientasi pada guru dengan materi yang disajikan dikemas dalam bentuk modul sehingga lebih cocok bagi siswa yang memiliki sikap wirausaha negatip, hal ini disebabkan siswa yang memilki sikap wirausaha negatip cenderung pasif menunggu bimbingan dari guru. Dengan demikian guru memiliki banyak kesempatan untuk memberikan motivasi, semangat dan arahan sehingga siswa lebih termotivasi dan terdorong dalam mengetahui dan memahami informasi penerapan teknologi dalam kehidupan seharihari dan meningkatkan hasil belajarnya. Akan tetapi jika pembelajaran model blok month release diberikan kepada siswa yang memilki sikap wirausaha positip akan menimbulkan kebosanan dan kejenuhan. Hal ini disebabkan proses pembelajaran terkesan monoton dan kurang memiliki variasi dalam penyajiannya serta pembelajaran kurang memberikan kesempatan kepada siswa untuk aktif dan kreatif. Dengan dimikian hasil belajar Tune Up Motor Bensin siswa yang memiliki sikap wirausaha negatip lebih tinggi jika dibelajarkan dengan model blok month release dibandingkan dengan siswa yang memiliki sikap wirausaha negatip jika dibelajarkan dengan menggunakan model blok week release. Dengan demikian pembelajaran model blok week release lebih tepat dibelajarakan kepada siswa yang memiliki sikap wirausaha positip dan pemberlajaran dengan menggunakan model blok month 
release lebih tepat diberikan kepada siswa yang memiliki sikap wirausaha negatip.

\section{PENUTUP}

Simpulan hasil penelitian ini adalah sebagai berikut:

1. Hasil belajar Tune Up Motor Bensin siswa dengan model week release lebih baik dibandingkan dengan model blok month release. Dalam hal ini siswa yang dibelajarkan dengan menggunakan model blok week release lebih baik dibandingkan dengan hasil belajar siswa yang dibelajarkan dengan model month release.

2. Hasil belajar siswa yang memiliki sikap wirausaha positip lebih baik dibandingkan dengan hasil belajar siswa yang memiliki sikap wirausaha negatip. Dengan demikian siswa yang memiliki sikap wirausaha positip memperoleh hasil belajar Tune Up Motor Bensin yang lebih baik dibandingkan dengan siswa yang memiliki sikap wirausaha negatip.

3. Terdapat interaksi antara pembelajaran model praktek dan sikap wirausaha dalam mempengaruhi hasil belajar Tune Up Motor Bensin.

\section{DAFTAR PUSTAKA}

Ahmadi, A. (2003). Psikologi Umum, Jakarta: Rineka Cipta.

Aribowo Prijosaksono dan Sri Bawono, (2004) The Power of Entrepreneurial Intelligence: Membangun Sikap dan Perilaku Entreprneur dalam Diri Anda I. Jakarta: Elex Media Komputindo.

Azwar, Saifuddin.(2011). Penyusunan Skala Psikologi. Yogyakarta: Pustaka Pelajar.
Barbara B. Seels \& Rita C.Richey, (1994), Teknologi Pembelajaran Defenisi dan Kawasaannya, Jakarta: Unit Penerbitan Universitas Negeri Jakarta (UNJ).

Dimyati \& Mudjiono, (2006). Belajar dan Pembelajaran, Jakarta, Rineka Cipta.

Miarso, Y., (2007), Menyemaih Benih Teknologi Pendidikan, Jakarta, Kecana.

Mudjiarto dan wahid, Aliaras, (2006). Membangun Karakter dan Kepribadian Kewirausahaan, Yogyakarta: Graha Ilmu.

Purwanto, N. M., (2007), Psikologi Pendidikan, Bandung, Remaja Rosdakarya.

Robert T. Kiyosaki, (2004) Business School: For People Who Like Helping People II; Jakarta: Gramedia Pustaka Utama.

Sadono Sukirno, (2006), Pengantar Bisnis, Jakarta, Kencana.

Sagala, Syaiful. (2009). Konsep dan Makna Pembelajaran. Bandung: CV.

Slameto, (2003), Belajar dan Faktor-faktor yang Mempengaruhinya, Jakarta, Rineka Cipta.

Stepen P. Robin (2003). Perilaku Organisasi.

Jakarta: Index.

Suryosubroto, B. (1997). Proses Belajar Mengajar Di Sekolah. Jakarta: PT. Rineksa Cipta

Syaiful, D. B. (2006). Strategi Belajar Mengajar. Jakarta : PT Rineka Cipta

Wena Made, (1996), Pendidikan Sistem Ganda, Bandung, Tarsito

Winkel, W.S. (2004). Psikologi Pengajaran. Jakarta: Gramedia.

Zalukhu, Sukawati \& Meyers, Koen, (2009), Panduan Dasar Pelaksanaan Ekowisata, Jakarta: Unesco Office. 